\title{
Evaluation of the anxiolytic activity of the leaves of Nymphaea lotus (Water Lily) in mice.
}

\author{
Aduema $W^{1 *}$, Akunneh-Wariso $\mathrm{C}^{2}$, Amah AK ${ }^{3}$, Vidona $\mathrm{WB}^{4}$ \\ ${ }^{1}$ Department of Medical Physiology, Gregory University, Uturu, Abia State, Nigeria \\ ${ }^{2}$ Department of Human Physiology, Abia State University, Uturu, Abia State, Nigeria \\ ${ }^{3}$ Department of Human Physiology, Imo State University, Imo State, Nigeria \\ ${ }^{4}$ Department of Human Anatomy, Enugu State University, Enugu State, Nigeria
}

\begin{abstract}
The anxiolytic effect of the leaves of water lily was investigated using mice as experimental animals. Thirty (30) were mice randomly divided into group 1,2 and 3 . Before the neurobehavioral parameters were assessed, the LD50 and the phytochemical screening of the leaves of the plant were determined. The open field maze and the transition box apparatus were used to determine the level of fear and anxiety related behaviors in mice. In the open field arena, the grooming frequency was statistically not different when compared to control. Stretch attend posture frequency (SAP) was statistically higher in the test groups when compared to control $(P<0.001)$. It was also observed that the frequency of defecation decreased in the treated groups when compared to the control group $(\mathbf{P}<\mathbf{0 . 0 1})$. The light duration box and frequency of transition were statistically higher $(\mathrm{P}<0.001)$ compared to control. Thus, the leaves of the plant tend to reduce the level anxiety in mice.
\end{abstract}

Keywords: Nymphaea lotus, Anxiety, Open field maze, Light/dark box, Mice.

Accepted on February 05, 2018

\section{Introduction}

Nymphaea lotus, commonly known as water lily, belongs to the family nymphaeaceae. The flowers are white, sometimes with a tinge of pink [1]. The plant is native to the Nile and is grown in various parts of East Africa and Southeast Asia [2]. The plant has different names depending on the tribes, for instance the Igbo call it 'Ijikara', Yoruba call it 'Iyeye 'while the Hausa call it 'Bado' [3]. It is commonly seen in freshwater ecosystem where it is scattered and seen floating on top of water bodies [4]. It is among the earliest aquatic macrophytes that have been identified in Nigerian freshwaters [5]. It is used in traditional medicine system as an aphrodisiac, anodyne, astringent, cardiotonic, sedative, demulcent, analgesic and as anti-inflammatory agent [6]. The plant is known to contain a lot of chemical compound. It has a calming and sedative effect on the nervous system, therefore it can be used in the treatment and management of insomnia and anxiety disorders [1]. Disorders of anxiety are neurological syndromes which are common among humans. However, modern synthesized drugs for these disorders are costly and not always readily available for people in the rural areas. Therefore it is important to carry out this study in order to provide solution to this problem using plant which will be more affordable with fewer side effects; hence, this study will go a long way in solving this problem (Figure 1).

\section{Materials and Methods}

\section{Animal care}

Thirty (30) Swiss white mice having a body weight between 20-25 grams were used in this research work. The animals were kept in the animal house of the Department of Physiology, Ututru, Abia State, Nigeria. The animals were kept in a

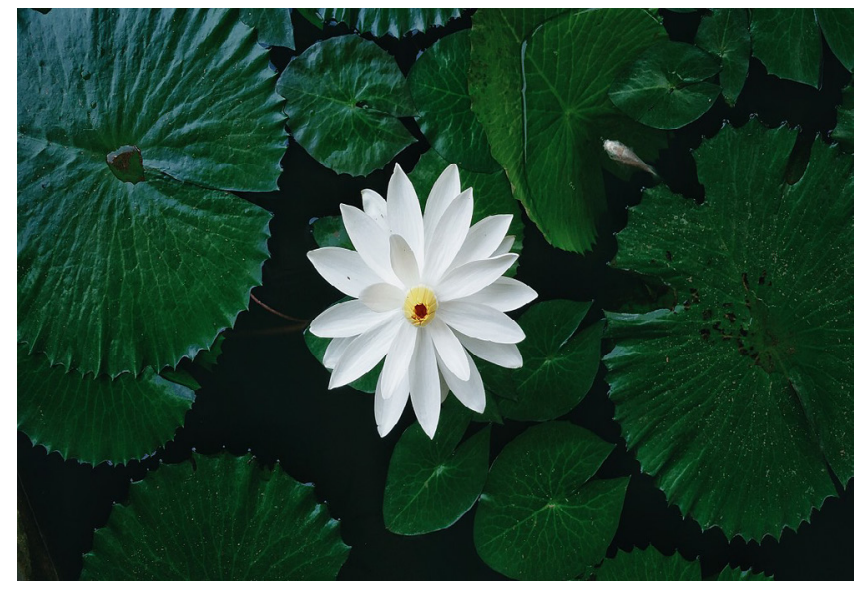

Figure 1. Nymphaea lotus leaves.

hygienic and well ventilated environment and maintained under standard environmental conditions. Animals were fed with normal rat chow and allowed water ad libitum for 21 days for acclimatization of the animals.

\section{Experimental design}

Thirty (30) Swiss mice were randomly divided into three groups 1,2 , and 3 of 9 mice per group. Group 1 was the control; groups 2 and 3 were for the treated groups respectively. Animals in group 1 received normal rat chow; group 2 animals received 20 $\mathrm{mg} / \mathrm{kg}$ and group 3 , received $40 \mathrm{mg} / \mathrm{kg}$ of the plant extract daily for a period of 30 days.

\section{Experimental procedures}

Open field test: Each mice was scooped up with a plastic container and then placed in the open field arena and allowed to 
Citation: Aduema W, Akunneh-Wariso C, Amah AK, et al. Evaluation of the anxiolytic activity of the leaves of Nymphaea lotus (Water Lily) in mice. Biol Med Case Rep. 2018;2(1):21-24.

explore the apparatus for 5 minutes and certain behaviors scores were taken into consideration, which are, stretch attend posture, center square entry, defecation and grooming, etc. (Figure 2).

\section{Light/dark transition box:}

a. Each mouse was picked by the base of its tail and placed in the center of the white compartment facing the door to the dark compartment and allowed to explore the apparatus for five minutes.

b. The mice behaviors were scored within the period and the maze was cleaned with alcohol between tests and then allowed to dry.

Behaviors scored included: Transition, light box duration, dark box duration, stretch attends posture, grooming, rearing which included urination and defecation (Figure 3).

\section{Results}

The light chamber duration which refers to the time spent in the light compartment of the light/dark transition box was higher for the low and high dose treated groups $(p<0.001)$ compared to control. However, the frequency of stretch attend posture for the test groups showed lower SAP 1 when compared to control $(\mathrm{P}<0.001)$. The frequency of grooming showed similar trend. The frequency of defecation for the treated groups were lower $(\mathrm{P}<0.001)$ when compared to control. The results also showed that the frequency of transition for the low and high dose groups were statistically higher $(\mathrm{P}<0.01)$ compared to control. However, the high dose group showed a significantly higher transition frequency $(\mathrm{P}<0.001)$ compared to control (Graphs 1-5).

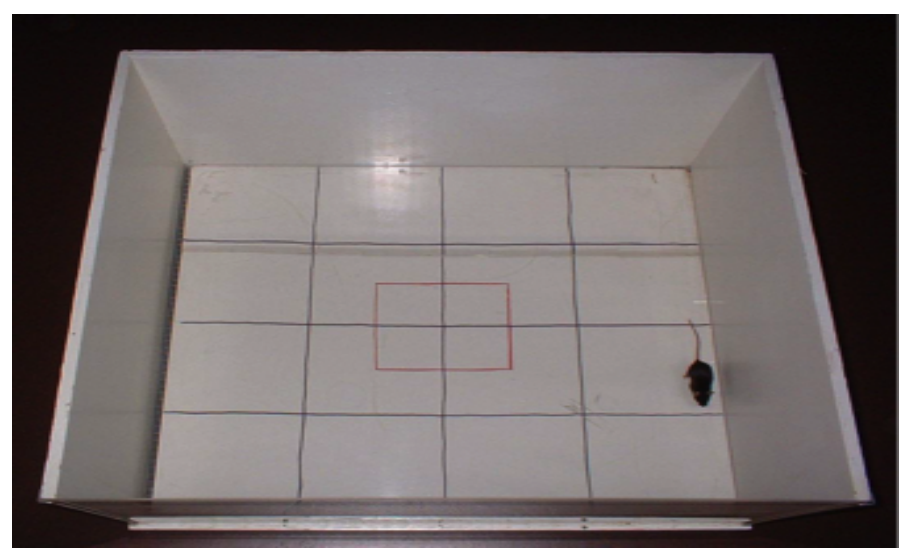

Figure 2. Open field maze.

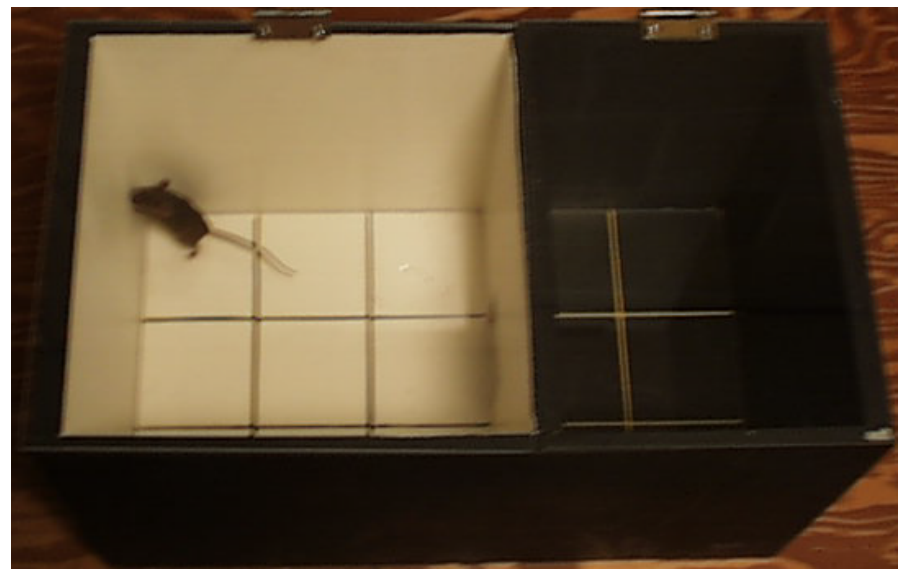

Figure 3. Light/dark transition box apparatus.

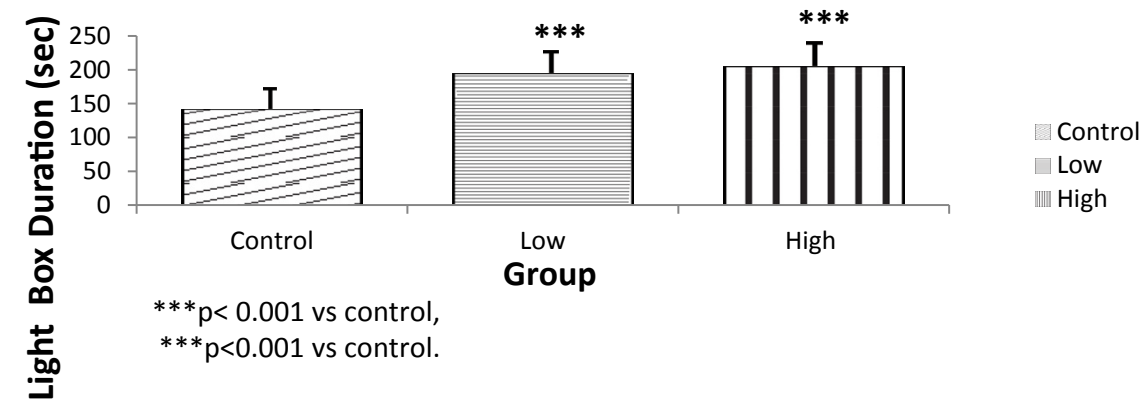

Graph 1. Light box duration in control and Nymphea lotus-treated groups. Values are mean + SEM, $n=9$.

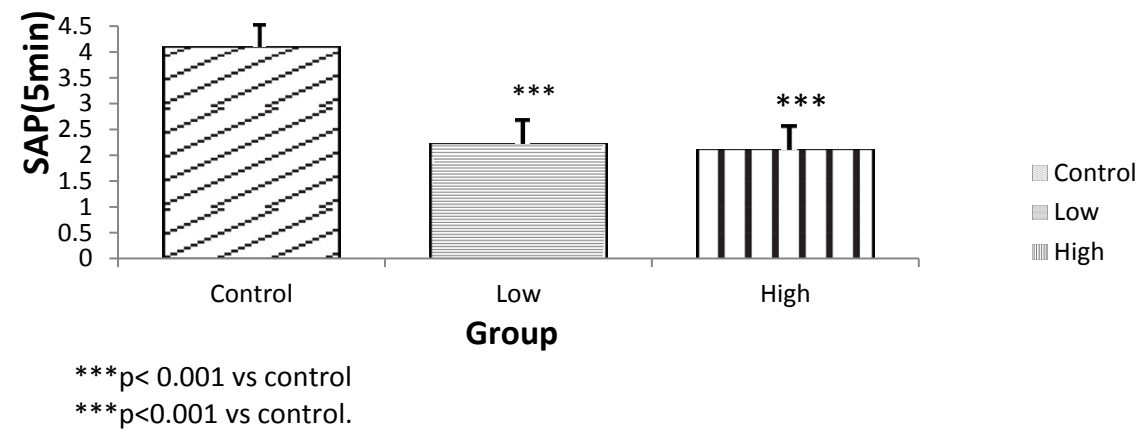

Graph 2. SAP in the light/dark transition box in the Nymphea lotus-treated groups and control. Values are mean $+S E M, n=9$. 


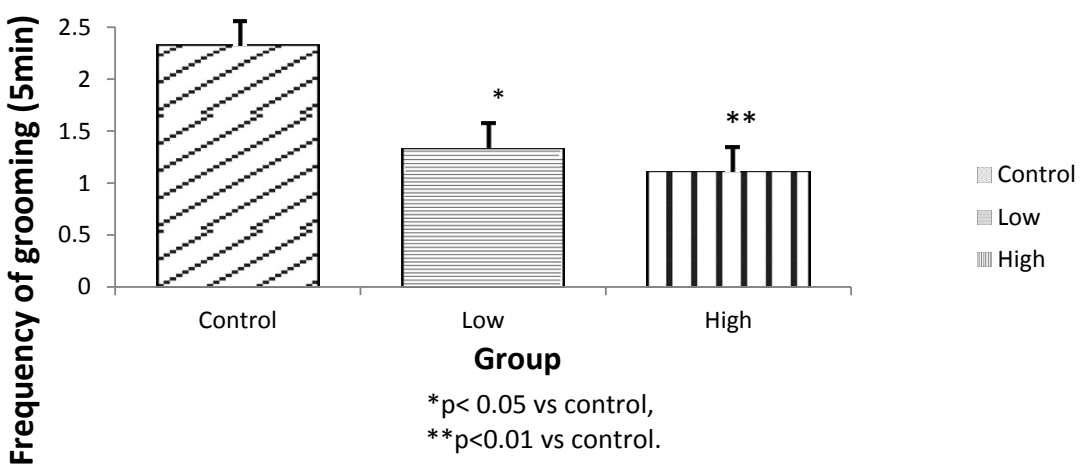

Graph 3. Frequency of grooming in the light/dark transition box b/w the Nymphea lotus-treated groups and control. Values are mean + SEM, $n=9$.

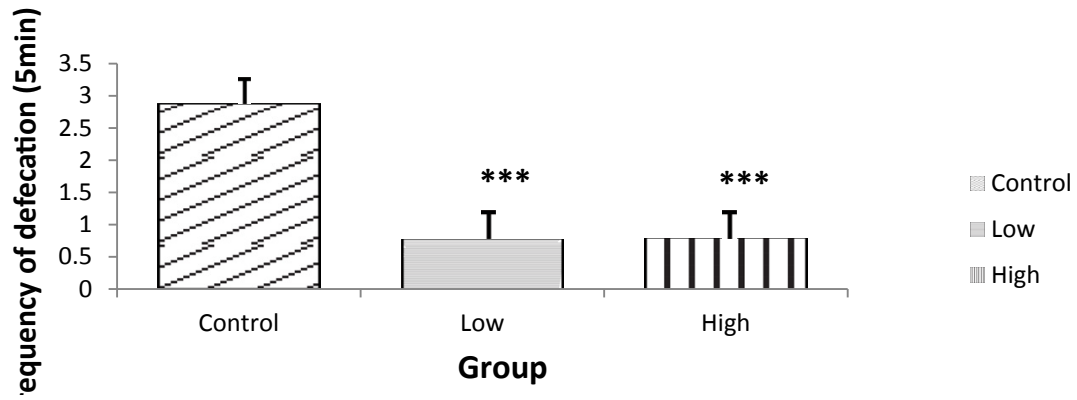

$* * * p<0.001$ vs control,

$* * * \mathrm{p}<0.001$ vs control.

Graph 4. Frequency of defecation in the light/dark transition box b/w the Nymphea lotus-treated groups and control. Values are mean + SEM, $n=9$.

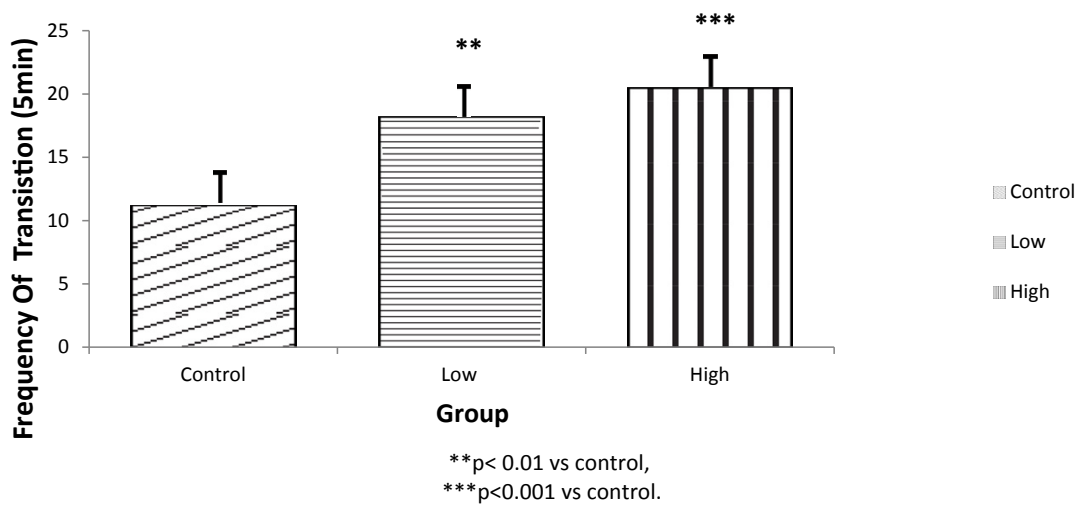

Graph 5. Comparison of frequency of transition in the light/dark transition box test in the Nymphea lotus-treated groups and control. Values are mean $+S E M, n=9$.

\section{Discussion}

The results of our exploration showed that in the open field arena, Stretch attend posture which is a risk assessment behavior were rodents demonstrate forward movement of the head and shoulder which is then followed by withdrawal of its head backwards to its initial position [7]. It is a behavior exhibited by rodents introduced in a new milieu and it is a used as a parameter to assess the level of anxiety in rodents. The low and high dose treated mice showed a significantly lower frequency of stretch attend posture when compared to the control. This indicates decrease in the level of anxiety. The results showed that the grooming frequency did not differ among the experimental groups. However, the number of fecal bole of the Nymphaea lotus fed mice was statistically lower as when compared to the control Hall [8]. Similarly, the frequencies of grooming, defecation and stretch attend posture in the lower and high dose treated group were significantly different when compared to control in the light/dark transition box experiment. This shows a decrease in the level of anxiety. The light/dark transition box test indicates that the test groups administered with the extract significant spent a longer time in the light compartment of the light/dark transition box than the untreated mice. This indicates that the treated animals did not mind the presence of light and their exposure to their surroundings, showing decreased anxiety and fear in the $N$. lotus treated mice [9]. The amydala is the part of the brain that controls the level of anxiety and fear [10]. Electrical stimulation of this area is associated with the feeling of fear and terror [10]. Therefore, it is likely that some unknown chemical compounds in the leaves of this plant could be responsible for the anxiolytic property exhibited by Nymphaea lotus thus reducing the excitability of the amydala thereby increasing the threshold by which the nuclei containing this cell respond which in turn decreases the level of anxiety and fear in the experimental animals $[11,12]$. 
Citation: Aduema W, Akunneh-Wariso C, Amah AK, et al. Evaluation of the anxiolytic activity of the leaves of Nymphaea lotus (Water Lily) in mice. Biol Med Case Rep. 2018;2(1):21-24.

\section{Conclusion}

Our findings showed that the leaves of $N$. lotus tend to reduce fear and anxiety level in mice. Therefore, the Medicinal potentials of Nymphaea lotus can be used by Pharmaceutical industries in producing drug for the treatment and management of anxiety disorders.

\section{References}

1. Afolayan AJ, Sharaibi OJ, Kazeem MI. Phytochemical analysis and in vitro antioxidant activity of Nymphaea lotus. Int J Pharmacol. 2013;9:297-304.

2. Abu-Zaida ME, Mashaly IA, Abd El-Monem M, et al. Economic potentials of some aquatic plants growing in North East Nile delta, Egypt. J Applied Sci. 2008;8:1395-1405.

3. Jethro K. Medicinal plant information. Back to Eden publishing CO., Lonia Linda.1994:11- 276.

4. Carlini EA. Plants and the central nervous system. Pharmacology, Biochemistry and Behavior. 2003;75:501-512.

5. Akinjogunla OJ, Adegoke AA, Udokang IP, et al. Microbial potential of Nymphaea lotus (Nymphaeaceae) against wound pathogens. J Med Plants Res. 2009;3:138-141.
6. Madhusudhanan N, Lakshmi T, Kumar SG, et al. In vitro antioxidant and free radical scavenging activity of aqueous and ethanolic flower extract of Nymphaea Alba. Int J Drug Dev Res. 2011;3:252-258.

7. Nilson RA. Qualitative and quantitative risk assessment of snuff dipping. Regulatory Toxicology and Pharmacology. 1998;28:1-16.

8. Hall CS. Emotional behavior in the rat. 1. Defecation and urination as measures of individual differences in emotionality. J Comp Psychol. 1934;18:382-403.

9. Bourin M, Hascoet M. The mouse light/dark box test. Eur J Pharmacol. 2002:55-65.

10. Osim EE. Analgesic activity of Vigna unguiculata in CD-1 mice following formalin administration. 2008:24-27.

11. Costall B, Jones BJ, Kelly ME, et al. Exploration of mice in a black and white test box: Validation as a model of anxiety. Pharmacology, Biochemistry and Behavior. 1989;32:777-785.

12. Adolphs R, Gasselin F, Buchanan TW, et al. Mechanism for impaired fear recognition after amygdala damage. Nature. 2005; 433:68-72.

\section{*Correspondence to:}

Aduema $\mathrm{W}$

Department of Medical Physiology

Gregory University

Uturu

Nigeria

Tel: +8038046678

E-mail: Wadioniaduema@gmail.com 